\title{
Öğretmenlik Uygulamasının Süre Açısından İncelenmesi ve Bir Çözüm Önerisi
}

\begin{tabular}{lccc}
\hline MAKALE TÜRÜ & Başvuru Tarihi & Kabul Tarihi & Yayın Tarihi \\
Araştırma Makalesi & 13.03 .2019 & 04.10 .2019 & 04.10 .2019 \\
\hline
\end{tabular}

\section{Figen Çam Tosun iD.}

Sinop Üniversitesi

\begin{abstract}
Öz
$\mathrm{Bu}$ araştırma öğretmen yetiştirme programlarında yer alan öğretmenlik uygulaması dersinin uygulanış süresiyle ilgili öğretmen adaylarının, uygulama öğretmenlerinin, okul yöneticilerinin ve öğretim elemanlarının görüşlerini ortaya çıkarmayı daha sonra da dünyadaki uygulamalarla karşılaştırma yapıp farklı bir uygulama önermeyi amaçlamaktadır. Nitel araştırma yöntemi ile tasarlanan araştırmanın çalışma grubunu öğretmenlik uygulamasına katılan sekiz eğitim fakültesi öğrencisi, sekiz uygulama öğretmeni, dört okul yöneticisi, sekiz öğretim elemanı olmak üzere toplam 28 kişi oluşturmaktadır. Veri toplama aracı olarak araştırmacı tarafindan hazırlanan görüşme formları kullanılmıștır. Verilerin analizinde içerik analizi tercih edilmiștir. $\mathrm{Bu}$ araştırmada öncelikle öğretmen adaylarının, uygulama öğretmenlerinin, okul yöneticilerinin ve öğretim elemanlarının görüşlerine göre okul uygulamasının süre açısından yetersiz olduğu ortaya konmuştur. Daha sonra Türkiye, Finlandiya, Singapur ve Almanya öğretmen yetiştirme programlarındaki okul uygulama sistemleri karşılaştırılmış, Türkiye'de uygulanan okul uygulamalarının süre olarak azlığı ortaya çıkmıştır. Bu yetersizliği giderebilmek için öğretmenlik uygulamaları kapsamında bir çözüm önerisinde bulunulmuştur.
\end{abstract}

Anahtar sözcükler: Öğretmenlik uygulaması, okul deneyimi, staj, öğretmen yetiştirme. 
Geleceğe yön vermek isteyen ülkelerin ilk yapması gereken işlerden biri eğitim sistemini iyileştirmek, çağa uygun hatta çağın ilerisinde yapılandırmaktır. Eğitim sisteminin iyi olması ülkenin bir eğitim felsefesinin olmasına, ülkedeki eğitim politikalarının işlevselliğine, okul yönetim anlayışlarına ve öğretmenlerin niteliğine bağlıdır. Atanur-Baskan, Aydın ve Madden'in (2006) eğitim sisteminin niteliğinin temel belirleyicisinin sistemin uygulayıcıları olan öğretmenler olduğunu söylemesi yerinde bir belirlemedir. Bu nedenle öğretmenlerin yetiştirilmesi büyük öneme sahiptir. Bilir (2011) öğretmenlerin iki temel özelliğini şöyle açıklamaktadır: "Birincisi, kişinin mesleğe yatkınlığı, öğretmenliğin gerektirdiği örnek olma nitelikleri ile insancıl, sevecen olma vb. kişisel özellikler, ikincisi ise genel kültür, alan bilgisi, öğretmenlik meslek bilgisinin oluşturduğu mesleki özelliklerdir” (s. 228) $\mathrm{Bu}$ özelliklerden ikinci maddede yer alanlar yani genel kültür, alan bilgisi ve öğretmenlik meslek bilgisi eğitim fakültelerinde kazandırılmaya çalışılmaktadır.

Öğretmen yetiştirme konusunda geçmişten günümüze kadar farklı uygulamalarla deneyim kazanılmaya çalışılmıştır. Cumhuriyetin ilk yıllarından itibaren öğretmen okullarıyla (muallim mektepleri), köy enstitüleriyle, yüksek öğretmen okullarıyla, eğitim enstitüleriyle sonrasında eğitim fakülteleriyle öğretmen yetiştirilmiştir (Akdemir 2013; Erdem, 2015). Bazen anlam vermekte zorlanılan mektupla öğretmenlik ya da formasyonla öğretmenlik gibi uygulamalar da yapılmışıır. Bu öğretmen yetiştirme denemelerinin içinde köy enstitüleri eğitim felsefesi ve yetiştirdiği öğretmenlerin niteliği konusunda dünyada örnek olacak bir yap1 sergilemiştir. 1982 yılından sonra öğretmen yetiştirmeyi üstlenen eğitim fakülteleri 1998, 2006 ve 2018 yıllarında öğretim programı değişiklikleri yapmıştır.

Öğretmenlik programları, kuramsal ve uygulama dersleri olarak iki grupta sınıflandırılabilir. Uygulama dersleri de bir öğretim dersinin uygulamasının yapılması ve öğretmenlik uygulaması olarak ayrılabilir. Öğretmenlik uygulaması öğretmen adayının eğitim gördüğü öğretmenlik alanında, yönetim ve ders dışı etkinliklerle birlikte sınıf içinde öğretmenlik becerisi kazandırmayı amaçlamakta ve öğretmen adayının belirli bir dersi ya da dersleri planlı bir şekilde öğretmesini sağlamaktadır (Milli Eğitim Bakanlı̆̆ı-MEB, 2018). Öğretmen yetiştirirken okulda uygulama yapma gereğini köy enstitülerinde yöneticilik yapmış olan Ağanoğlu (1949) köy enstitülerindeki öğrencilerin yetiştirilmesi sırasında köy uygulamalarını anlatırken şöyle açıklamaktadır:

Daima şikâyet ediliyor: Okul ile hayat birbirini tutmuyor. Yetişen gençler okulun temiz havası içinden hayatı seyir ediyorlar ve sonra hayata atılınca münkesir ve münferit oluyorlar. Hayat şartlarına uymak için yeniden kıymetler kazanmaya ve yeni bir mantalite iktisap etmeye koyuluyorlar. Bu inkisar ve infiali nispeten önlemek ve hayat şartlarına uyabilmeyi daha kolay bir hale getirmek için müesseseleri hayat ile iç içe bulundurmaya çok yer vermek bir terbiye prensibidir. (ss. 61-62)

Sistemin uygulayıcıları olan öğretmenlerin de öğretmen yetiştirme ve öğretmenlik uygulamalarıyla ilgili düşünceleri önemsenmelidir. Öğretmenlerin 
mesleklerinde yaşadıklarına ve değerlendirmelerine dayanan "Tutkulu Bir Mücadele Öğretmenlik" adlı kitapta bazı öğretmenlerin öğretmenlik uygulamasıyla ilişkili değerlendirmeleri şöyle paylaşılmıştır (Tüfekçi ve Ural, 2015):

Üniversitede dört yıl boyunca, kendimi bir fanusun içinde yaşıyormuş gibi hissettim. Her şey yapaydı. Denize açıldığımda neler yapabilecektim, nelerle karşılaşacaktım?”, “Üniversite yaşamıma baktığımda uygulama derslerinin daha fazla olmasının ve bunların yapay bir ortam yerine gerçek yaşamda uygulama firsatı verilmesinin daha uygun olacağını düşünüyorum. Hakan Mutlu. (s. 69)

"Hangi eğitim bana bu yaşadıklarım için pratik bilgiyi verebilirdi? Bu kadar yaşanmışlık hangi ders kitabında sunulabilir? Yaşayınca anladım. .... Berçem B. Altunakar" (s. 39).

Geçmişte yöneticilik yapmış eğitimcilerin de günümüzde mesleğini yapan öğretmenlerin de ifadelerindeki ortak nokta, öğretmen olmak için yetiştirilirken öğrencilerin eğitimlerine gerçek yaşamı / okulu daha çok dâhil etmek gerektiğidir.

Ekonomik Kalkınma ve İşbirliği Örgütü (The Organisation for Economic Cooperation and Development-OECD) (2014) ülkelerinin büyük çoğunluğunda öğretmenlik uygulaması zorunludur. OECD (2014) verilerine göre 36 ülkenin okul uygulama süreleri içinde en düşük sayı 20 gün ile Japonya ve 30 gün ile de Türkiye’ye aittir. Verilerini paylaşan ülkelerin yarısında okul uygulama süreleri 70 gün ve üzerindedir. Almanya'da okul uygulama süresi en az 282 gün ile dikkat çekicidir. Almanya'da öğretmen adayları eğitimleri sırasında yaptıkları öğretmenlik uygulamasının dışında I. Devlet Sınavını geçtikten sonra Hazırlık Hizmet Aşaması olarak en az 12 aylık bir öğretmenlik uygulamasına katılırlar (Erben Keçici, 2011; Eurydice, 2009). Hollanda' da öğretmen adayları ilk iki yılda haftada bir gün, üçüncü yıl bir buçuk gün, dördüncü ve son bir yılda ya altı ay boyunca tam ya da bir yıl boyunca haftada üç gün staj yapmaktadırlar (Cirit-Gül, 2016; Ergun ve Ersoy, 2014). Aykaç, Kabaran ve Bilgin (2014) bazı ülkelerin öğretmenlik eğitimlerini karşılaştırmalı olarak ele almışlardır. Buna göre Fransa'da iki yıl, İngiltere'de bir ya da iki yıl öğretmenlik uygulaması yapılmaktadır. Fransa'da öğretmen yetiştiren kurumlara göre farklılık olsa da temelde dört ayrı staj görülmektedir. İlki gözlem stajıdır; bu staj mesleği ve okulu tanımaları için yapılır ve iki haftadır. Rehberli uygulama stajı, öğretim yılının başında ya da içinde bir rehber öğretmenle birlikte haftada bir gün olmak üzere üç-dört hafta uygulanmaktadır. Sorumlu uygulama staj1, bir yıl devam eder. Öğretmen adayları tek başına sınıfın sorumluluğunu üstlense de rehber öğretmen gözetimi devam eder. Son olarak bir de okul dışında ticari bir ortamda, iş ortamlarını tanımaları amacıyla üç haftalık bir uygulama olan şirket stajı yaparlar (Uygun, Ergen ve Öztürk, 2011). Amerika'da da farklı uygulamalar olsa da Michigan Üniversitesinde ilkokul öğretmenliği lisans eğitim programı üç dönem uygulamayı (practicum) ve bir dönem de stajyer öğrenciliği (student teaching) içermektedir (Atanur-Baskan ve diğ., 2006). Finlandiya'da ise öğretmen adayları iki yıl uygulama eğitimine katılmaktadır. Finlandiya'da eğitim fakültelerine bağlı 
uygulama okulları bulunmaktadır ve öğretmen adayları ilk üç aşamayı bu uygulama okullarında, diğer aşamayı da devlet okulunda geçirir (Aras ve Sözen, 2012; Mete, 2013).

Türkiye'de ise 2006 yılı programlarına göre Okul Öncesi Öğretmenliği, Sınıf Öğretmenliği ve Özel Eğitim Öğretmenliği programlarında bir dönem boyunca haftada yarım gün Okul Deneyimi dersi, iki dönem boyunca haftada bir gün Öğretmenlik Uygulaması dersi uygulanmaktadır. Diğer öğretmenlik programlarında ise bir dönem haftada yarım gün Okul Deneyimi ve bir dönem haftada bir gün Öğretmenlik Uygulaması dersi uygulanmaktadır (Yükseköğretim Kurulu-YÖK, 2007). 2018 yılında yenilenen programlarda bütün bölümlerde 4. sınıfın ilk döneminde Ögretmenlik Uygulaması 1 ve 4. sinıfin ikinci döneminde Öğretmenlik Uygulaması 2 şeklinde uygulanacaktır (YÖK, 2018). Bu derslere göre haftada bir gün 6 saat ilkokul, ortaokul ya da liselerde uygulama yapılmaktadır. Bir öğrenci bir dönemde devamsızlık yapmadığı takdirde 12 gün, iki dönemde toplam 24 gün öğretmenlik uygulaması yapmaktadır.

Alanyazın taramasında öğretmenlik uygulaması dersinin öğretmen adaylarının, öğretmenlerin ya da öğretim elemanlarının görüşlerine göre değerlendirildiği (ör: Altıntaş ve Görgen, 2014; Arıkan, 2009; Aslan ve Sağlam, 2018; Azar,2003; Baştürk, 2009; Becit, Kurt ve Kabakçı, 2009; Gökçe ve Demirhan, 2005; Özkılıç, Bilgin ve Kartal, 2008) pek çok araştırmaya ulaşılmıştır. Bu araştırmalarda genel olarak ders kapsamında yaşanan sorunlar ele alınmıştır. Araştırmalar, bu dersin etkin ve verimli geçmediği konusunda yoğunlaşmaktadır. Dersin etkin ve verimli geçmemesinin uygulama süresiyle de ilişkili olabileceği düşünülmektedir. Dünyada içinde Türkiye'nin de olduğu çok az ülkede öğretmenlik uygulaması 30 günün altında gerçekleşmektedir. Eğer öğretmen adayları gerçek sorunlarla daha fazla yüzleşirlerse sorunlarla daha iyi mücadele edebileceği düşünülmektedir. $\mathrm{Bu}$ nedenle bu araştırmanın problem durumunu eğitim fakültesi öğrencilerinin aldığı öğretmenlik uygulaması dersinin süre yönünden kısa olması oluşturmaktadır.

\section{Amaç}

$\mathrm{Bu}$ araştırma, öğretmen yetiştirme programlarında yer alan öğretmenlik uygulaması dersinin uygulanış süresiyle ilgili öğretmen adaylarının, uygulama öğretmenlerinin, okul yöneticilerinin ve öğretim elemanlarının görüşlerini ortaya çıkarmayı daha sonra da dünyadaki uygulamalarla karşılaştırma yapıp farklı bir uygulama önermeyi amaçlamaktadır. Bu kapsamda aşağıdaki sorulara yanıt aranmıştır:

1. Öğretmen yetiştirme programlarındaki öğretmenlik uygulamalarının uygulanış süresiyle ilgili öğretmen adaylarının görüşleri nedir?

2. Öğretmen yetiştirme programlarındaki öğretmenlik uygulamalarının uygulanış süresiyle ilgili uygulama öğretmenlerinin görüşleri nedir? 
3. Öğretmen yetiştirme programlarındaki öğretmenlik uygulamalarının uygulanış süresiyle ilgili okul yöneticilerinin görüşleri nedir?

4. Öğretmen yetiştirme programlarındaki öğretmenlik uygulamalarının uygulanış süresiyle ilgili öğretim elemanlarının görüşleri nedir?

5. Türkiye, Singapur, Finlandiya ve Almanya'da öğretmenlik uygulaması nasıl yapılmaktadır?

6. Öğretmen yetiştirme programlarındaki öğretmenlik uygulamalarının yerine farklı bir uygulama söz konusu olabilir mi?

\section{Yöntem}

$\mathrm{Bu}$ bölümde araştırma modeli, çalışma grubu, veri toplama aracı, verilerin toplanması ve analizinden bahsedilmiştir.

\section{Araştırma Modeli}

$\mathrm{Bu}$ araştırmada ilk olarak öğretmenlik uygulamasına katılan bileşenlerin, öğretmenlik uygulama dersinin süresiyle ilgili düşünceleri ortaya çıkarılmıştır. Uygulama süresinin sayısal olarak yeterli olup olmamasından daha çok bu sürede yaşanan durumların derinlemesine incelenmesi amaçlandığından nitel araştırma yöntemi kullanılmaya karar verilmiştir. Nitel araştırmalar katılımcıların neler yaşadığına yoğunlaşarak olguları, durumları doğal ortamında inceler (Denzin ve Lincoln, 2005; Merriam, çev. 2013; Silverman, 2005). Nitel yöntemlerden görüşme formları tercih edilmiştir. Görüşme formlarının tercih edilme nedenlerinden biri katılımcıların ses kaydı vermek istememeleri, diğeri ise görüşme formlarının kişilerin görüşlerini doğrudan almayı sağlamasıdır (Türnüklü, 2000; Yıldııım, 1999).

\section{Çalışma Grubu}

Araştırmada çalışma grubu belirlenirken amaçlı örnekleme yöntemi tercih edilmiştir. Öncelikle iki okul belirlenmiştir. Okullardan biri şehir merkezinde bulunmaktadır. Şehir merkezinde bulunan bu okulun olanakları ve velilerin sosyoekonomik ve kültürel yapısı diğerlerine göre daha yüksektir. Diğer okul ise şehir merkezinden oldukça uzaktadır. İkinci okulun olanakları ve veli profili diğer okulun sahip olduğundan oldukça farklıdır. Öğretmenlik uygulamasına katılan bileşenlerin temsil edilmesine dikkat edilmiştir. Katılımcılar seçilirken çeşitlilik ilkesine dikkat edilmiştir. Buna göre öğretmenlik uygulamasına giden eğitim fakültesi sınıf öğretmenliği sekiz son sinıf öğrencisi (öğretmen adayı), sekiz uygulama öğretmeni, dört okul yöneticisi, sekiz öğretim elemanı olmak üzere toplam 28 kişi rastgele seçilmiştir. Katılımcılara ait betimsel bilgiler Tablo 1'de verilmiştir. 
Tablo 1

Katılımclların Betimsel Bilgileri

\begin{tabular}{llllll}
\hline & & $\begin{array}{l}\text { Öğretmen } \\
\text { Adayı }\end{array}$ & $\begin{array}{l}\text { Uygulama } \\
\text { Öğretmeni }\end{array}$ & $\begin{array}{l}\text { Okul } \\
\text { Yöneticisi }\end{array}$ & $\begin{array}{l}\text { Öğretim } \\
\text { Elemanı }\end{array}$ \\
\hline \multirow{2}{*}{ Cinsiyet } & Kadın & 7 & 5 & 1 & 3 \\
& Erkek & 1 & 3 & 3 & 5 \\
\hline Hizmet & $10-15$ & - & 4 & 1 & 4 \\
y1lı & $16-20$ & - & 3 & 1 & 4 \\
& $21+$ & - & 1 & 2 & - \\
\hline
\end{tabular}

\section{Veri Toplama Araçları}

Öğretmenlik uygulaması dersini alan öğrenciler, uygulama öğretmenleri, okul yöneticileri ve öğretim elemanları için aynı içerikte yarı yapılandırılmış görüşme formları hazırlanmıştır. Araştırmacı tarafından hazırlanan yarı yapılandırılmış görüşme formları uzman görüşüne sunulmuştur (Eğitim Yönetimi Uzmanı ve Ölçme Değerlendirme Uzmanı üç öğretim elemanı). Gelen dönütler doğrultusunda görüşme formlarına son hali verilmiştir. Buna göre öğrenciler için hazırlanan formda 13 açık uçlu soru, uygulama öğretmeni için hazırlanan formda 14 açık uçlu soru, okul yöneticisi için hazırlanan formda 10 açık uçlu soru, öğretim elemanı için hazırlanan formda 14 açık uçlu soru bulunmaktadır.

\section{Verilerin Toplanması ve Analizi}

Verilerin toplanması için ilk başta görüşme planlanmıştır ancak katılımcıların görüşme yapmak istememesi, sesli kayıt istememesi gibi nedenlerden dolayı görüşme formları oluşturulmuş ve uygulama okullarına gidilerek uygulama öğretmenleri ve okul yöneticilerine elden verilmiştir. Bir hafta sonra görüşme formları alınmıştır. Öğretim elemanları ve öğretmen adaylarına ise formlar eğitim fakültesinde elden verilmiş ve bir hafta sonra toplanmıştır. Verilerin analizinde içerik analizi tercih edilmiştir. Önce temalar oluşturulmuş aynı tema kapsamındaki sorular katılımcıların tekrarları doğrultusunda kodlanmıştır. Kodlara ilişkin sıklıklar bulunmuş, ayrıca anlaşılabilirliği artırmak için katılımcıların sözleriyle desteklenmiştir. Araştırmanın güvenirliğini sağlamak için Miles ve Huberman'ın önerdiği formül uygulanmıştır. Verilerin kodlaması yapıldıktan sonra bir ay beklenmiş ve tekrar kodlama yapılmıştır. Uyuşum düzeyini görmek için Güvenirlik = [Görüş Birliği / (Görüş Birliği + Görüş Ayrılığı)] x 100 (Miles ve Huberman, 1994) işlemi yapıllmıştır. Buna göre güvenirlik \% 96 olarak hesaplanmıştır.

\section{Bulgular}

Araştırma soruları kapsamında Eğitim Fakültesi son sınıf öğrencilerinden, öğretmenlik uygulamasına gittikleri okulların öğretmenlerinden, okul yöneticilerinden ve fakültedeki ders sorumlusu öğretim elemanlarından elde edilen verilerden öncelikle temalar oluşturulmuştur. Oluşturulan temalar aşağıda sunulmuştur: 
1. Öğretmen adayının kısa süreli öğretmenlik uygulamasının sınıfa yansıması

2. Öğretmen adayının kısa süreli öğretmenlik uygulamasının okula yansıması

3. Öğretmen adayının kısa süreli öğretmenlik uygulamasının yeterliğine ilişkin görüşler

Son araştırma sorusu doğrultusunda dünyadaki okul uygulamaları karşılaş̧ırmalı olarak verilmiştir.

\section{Öğretmen Adayının Kısa Süreli Öğretmenlik Uygulamasının Sınıfa Yansıması}

Eğitim fakültesi son sınıf öğrencilerinin haftada bir gün öğretmenlik uygulaması yapmak için gittiği okulda dersine girdiği öğrencileri tanıyıp tanımadığına yönelik sorulan soruya ilişkin oluşturulan kodlar ve bunların sıklıkları Tablo 2'de sunulmuştur.

Tablo 2

Öğretmen Adayının Öğrencilerini Tanımasına İlişkin Bulgular

\begin{tabular}{llll}
\hline Kodlar & $\begin{array}{l}\text { Öğretmen } \\
\text { Adayı }\end{array}$ & $\begin{array}{l}\text { Uygulama } \\
\text { Öğretmeni }\end{array}$ & $\begin{array}{l}\text { Öğretim } \\
\text { Elemanı }\end{array}$ \\
\hline Evet, öğrencileri tanır. & 2 & 1 & 1 \\
Bazılarının yüzlerini / isimlerini bilir. & 2 & - & - \\
Kişisel özelliklerini bilmez. & 1 & - & - \\
Yeterince tanımaz. & 2 & 3 & - \\
Hayır, tanımaz. & 3 & 4 & 5 \\
Adayın dikkatine bağlı olarak değişir. & - & - & 2 \\
\hline
\end{tabular}

Tablo 2'de görüldüğü gibi öğretmenlik uygulamasına giden öğretmen adaylarının kendileri uygulama sınıfındaki öğrencileri tanımadıklarını (3) ya da çok iyi tanıyamadıklarını (3) söylemişlerdir. Uygulama öğretmenlerinin (7) ve öğretim elemanlarının (5) çoğunluğu ise öğretmen adaylarının öğrencileri tanımadıklarını ya da yeterince tanımadıklarını ifade etmişlerdir. Katılımcılardan bazılarının konuyla ilgili görüşleri aşağıda verilmiştir:

"Hayır. İsim olarak belki birazını tanıyabiliyorum ama yeterli değil. Yeteri kadar gözlem yapılmıor" (Ö. Adayı 6).

"Stajyerimiz haftada bir gün geliyor ve okuldaki bütün sınıflarda ikişer hafta dönüşümlü giriyor. $\mathrm{Bu}$ da öğrencileri yeterince tanımalarına firsat vermiyor" (Öğretmen 5).

"Tanımalarının imkânsız olduğu aşikâr bir durum. Mevcut sınıf öğretmenleri bile bu çocukları ancak bir yıllık bir süreçte tanıma firsatı buluyorken bir günde ancak çocuğun ismini öğrenebilirsiniz" (Öğretim Elemanı 3).

Öğretmen adaylarının uygulama okulundaki öğrencilerinin isimlerini bilmesi, yönergeler sunabilmesi, sesini doğru kullanabilmesi, uygun zamanda etkili sorular 
sorabilmesi gibi öğrencilerle uygun iletişim kurma becerisine sahip olabilmesiyle ilgili veriler Tablo 3 'te sunulmuştur.

Tablo 3

Öğretmen Adayının Öğrencilerle Iletiş̧imine İlişkin Bulgular

\begin{tabular}{lllll}
\hline Kodlar & $\begin{array}{l}\text { Öğretmen } \\
\text { Adayı }\end{array}$ & $\begin{array}{l}\text { Uygulama } \\
\text { Öğretmeni }\end{array}$ & $\begin{array}{l}\text { Okul } \\
\text { Yöneticisi }\end{array}$ & $\begin{array}{l}\text { Öğretim } \\
\text { Elemanı }\end{array}$ \\
\hline Hayır, olanaklı olmuyor. & 4 & 3 & 2 & 1 \\
K1smen kurabiliyor. & 3 & 5 & 2 & 5 \\
Evet, kurabiliyor. & 1 & - & - & 1 \\
Adaya bağlı. & - & - & - & 1 \\
\hline
\end{tabular}

Öğretmen adaylarından sadece biri tam olarak iletişim kurabildiğini düşünmektedir. Diğer yedi öğretmen adayı ya iletişim kuramadığını ya da kısmen kurabildiğini söylemiştir. Uygulama öğretmenlerinden ve okul yöneticilerinden hiç kimse öğrencilerle tam olarak iletişim kurabildiklerini düşünmüyor. Öğretim elemanlarının da yarıdan fazlası kısmen iletişim kurabildiklerini ifade etmişlerdir. Katılımcıların öğretmen adaylarının öğrencilerle iletişim kurmalarıyla ilgili ifadeleri aşağıda verilmiştir:

"Haftada bir gün gidince çocukların çok az bir kısmıyla iletişim kurabiliyoruz. Sınıfın hepsine hakim olamıyoruz. Çocuklara tam alıştık derken dönem bitiyor" (Ö. Aday1 3).

"Çocuklar iletişime açılar. Eğer stajyer öğrenci iletişim kurmak isterse iletişim kuramaması mümkün değil. Teori ile pratik farklı. Ancak her stajyeri aynı isteğe sahip görmüyorum" (Öğretmen3).

“Öğrencilerle (bir günlük) iletişim kuruyorlar. Ancak öğretmen öğrenci ilişkisi tam kurulamıyor. Öğrencilere karşı kurallar koymada sıkıntılar olabiliyor” (Yönetici 2).

"Diyalog kurma, teneffüslerde oyun oynama gibi yollarla iletişim kurabiliyorlar. Fakat öğrenme öğretme süreci açısından bakıldığında öğrenciyi tanımama kaynaklı iletişim engelleri yaşanıyor" (Öğretim Elemanı 5).

Eğitim fakültesi öğrencileri genellikle eğitimlerinin üçüncü yıllarında Sinıf Yönetimi dersi almaktadırlar. Fakat bu kuramsal bir derstir ve uygulama alanı yoktur. $\mathrm{Bu}$ konudaki öğrenmelerini öğretmenlik uygulamasında göstermeleri beklenir. $\mathrm{Bu}$ nedenle öğretmen adaylarının sınıf yönetimine yönelik becerileri ile ilgili katılımcıların görüşleri doğrultusunda oluşturulan kodlar ve bunların sıklıkları Tablo 4 'te verilmiştir. 
Tablo 4

Öğretmen Adayının Sinıf Yönetimi Becerilerine İlişkin Bulgular

\begin{tabular}{llll}
\hline Kodlar & $\begin{array}{l}\text { Öğretmen } \\
\text { Adayı }\end{array}$ & $\begin{array}{l}\text { Uygulama } \\
\text { Öğretmeni }\end{array}$ & $\begin{array}{l}\text { Öğretim } \\
\text { Elemanı }\end{array}$ \\
\hline Sinıf yönetimini sağlıyor. & 2 & 1 & 1 \\
Sinıf yönetimini kısmen sağlıyor. & - & 7 & 5 \\
Sinıf yönetimini sağlamada zorlanıyor. & 6 & - & 2 \\
\hline
\end{tabular}

Öğretmen adaylarından sadece ikisi sınıf yönetimini sağladığını düşünüyor. Onlar da nasıl sağladığını, "Bağırarak sağlıyorum." ya da "Sorun çıkaran öğrenciyle birebir görüşüyorum." ifadeleriyle açıklamışlardır. Sınıf yönetimini sağlamada zorlanan diğer öğretmen adayları zorluk yaşamalarını "öğrencilerin kendilerini yeterince tanımamasına ve stajyer algısına" bağlamaktadırlar. Uygulama öğretmenlerinin çoğunluğu (7), öğretmen adaylarının kısmen sınıf yönetimini sağladıklarını düşünmektedir. Öğretim elemanlarından ise bir kişi sınıf yönetimini sağladıklarını ifade etmiştir. Öğretim elemanı bunu açılarken "uygulama öğretmeninin de yardımıla" ifadesi dikkat çekicidir. Başka bir öğretim elemanı ise sınıf öğretmeninin sınıfta olmasını dezavantaj olarak ele almıştır. Öğretim elemanlarının yarıdan fazlası (5) öğretmen adaylarının sınıf yönetimini kısmen sağlayabildiklerini düşünmektedirler. Öğretmen adaylarının sınıf yönetimini sağlamaları konusunda katılımcılar şu sözleri paylaşmıştır:

"Başka bir öğretmenin sınıfı olduğu için zor oluyor. Öğrenciler bizi öğretmen olarak görmüyorlar. Bazı sınıflarda yönetimi sağlamak kolay olsa da öğrenciler yeterince tanımadığı için zor oluyor" (Ö. Adayı 4).

"Yeterince sağlayamıyorlar. Uygulamaları süresince dört ders anlatıyorlar. Bunun yeterli olduğunu düşünmüyorum. Son haftalarda tüm gün için ders anlatmalarının daha yararlı olacağını düşünüyorum" (Öğretmen 5).

"Özellikle ders anlatımı esnasında sınıf öğretmeninin de sınıf ortamında bulunuyor olması öğretmen adayını sınıf yönetimi konusunda sınırlandırmaktadı"” (Öğretim Eleman13).

Öğretmen adaylarının birkaç ay sonra mezun olup atanma durumları göz önüne alındığında sınıfta etkin öğrenme ortamı oluşturmaları daha anlamlı olmaktadır. Bu nedenle öğretmen adaylarının sınıf içinde etkin öğrenme ortamı oluşturup oluşturamadığına yönelik sorulan sorunun kodları ve bunların sıklıkları Tablo 5'te verilmiştir. 
Tablo 5

Öğretmen Adayının Etkili Öğrenme Ortamı Oluşturmasına İlişkin Bulgular

\begin{tabular}{llll}
\hline Kodlar & $\begin{array}{l}\text { Öğretmen } \\
\text { Adayı }\end{array}$ & $\begin{array}{l}\text { Uygulama } \\
\text { Öğretmeni }\end{array}$ & $\begin{array}{c}\text { Öğretim } \\
\text { Elemanı }\end{array}$ \\
\hline Evet, oluşturabiliyor. & 3 & - & 1 \\
Hayır, oluşturamıyor & 1 & 5 & 5 \\
Kısmen oluşturabiliyor. & 4 & 2 & 2 \\
Adayın hazırlığına göre değişir. & - & 1 & - \\
\hline
\end{tabular}

Tablo 5'te görüldüğü gibi öğretmen adaylarının çoğunluğu az ya da çok etkili bir sınıf ortamı oluşturabildiğini düşünmektedir. Ancak uygulama öğretmenlerinin ve öğretim elemanlarının çoğunluğu, öğretmen adaylarının uygun ortamı oluşturamadığını düşünmektedir. Adaylar ile uygulama öğretmeni ve öğretim elemanları arasındaki fark dikkat çekicidir. Bu durum aşağıda verilen ifadelerle betimlenmeye çalışılmıştır:

"Şimdiye kadar öğrendiklerimizi uygulamaya çalışıyoruz. Fakat fakültedeki öğrendiklerimiz uygulamada yetersiz kalıyor. $\mathrm{Bu}$ durumlarda kendi öğrendiklerimizden, bildiklerimizden faydalanıyoruz. Eksiklerimizi kapatmaya çalışıyoruz" (Ö. Adayı 4).

"Stajyerin tecrübe kazanması bakımından süre az" (Öğretmen 2).

"Etkili öğrenme ortamı oluşturabilme açısından elbette ki daha uzun bir sürece ihtiyaçları var. Materyal hazırlama, etkinlik düzenleme vb. konularda eksikliklerini gidermeleri için daha fazla deneyime ihtiyaçları var" (Öğretim Elemanı 1).

Öğretmen adaylarının ölçme değerlendirme etkinlikleri yapmaları, kendilerini görme anlamında da önemli bir eğitim uygulamasıdır. Uygulama sınıflarında hem kendi işledikleri dersin ölçme değerlendirme etkinlikleri hem de sınıfın genel ölçme ve değerlendirme etkinlikleri ile ilgili becerilerine ilişkin katılımcı görüşlere dayalı kodlar ve bunların sıklıkları Tablo 6'da sunulmuştur.

Tablo 6

Öğretmen Adayının Ölçme Dĕgerlendirme Becerilerine İlişkin Bulgular

\begin{tabular}{llll}
\hline Kodlar & $\begin{array}{l}\text { Öğretmen } \\
\text { Adayı }\end{array}$ & $\begin{array}{l}\text { Uygulama } \\
\text { Öğretmeni }\end{array}$ & $\begin{array}{l}\text { Öğretim } \\
\text { Elemanı }\end{array}$ \\
\hline Kendi dersi sonunda yapıyor. & 5 & 5 & 2 \\
Yapmiyor. & 3 & - & 3 \\
Kismen yapıyor. & - & 1 & 3 \\
Zaman yeterli olmuyor. & - & 2 & 1 \\
\hline
\end{tabular}

Öğretmen adayları çoğunlukla anlattıkları dersin sonunda ölçme değerlendirme yaptıklarını belirtmiştir. Öğretmen adayları yapmama nedenlerini açıklarken kendilerine firsat verilmediğini ya da bu etkinliklerin istenmediğini söylemişlerdir. 
Uygulama öğretmenlerinin çoğunluğu (5) öğretmen adaylarının ders sonunda ölçme değerlendirme etkinlikleri yaptığını belirtmiştir. Uygulama öğretmenlerinden ikisinin ise zaman yetersizliğinden yapamadıklarını söylemesi önemli bir bulgudur. Öğretim elemanlarının çoğunluğu da öğretmen adaylarının ölçme değerlendirme etkinlikleri yapmadıklarını, yapamadıklarını ifade etmişlerdir. Katılımcıların ifadelerine göre derslerin dönem içi genel ölçme değerlendirme etkinliklerine ise öğretmen adaylarının hiç katılmadığı görülmektedir. Katılımcıların görüşleri aşağıda verilmiştir:

"Sadece bize söylenince yapıyoruz. Çünkü öbür türlü buna pek firsatımız olmuyor. Yani firsat da verilmiyor bu da acemi olduğumuzdan ya da yapamayacağımız düşünüldüğü için muhtemelen" (Ö. Adayı 1).

“Zaman yeterli olmuyor" (Öğretmen 4).

“Öğrencileri tanımadıkları için (düzeylerini bilme, konunun öncesini bilme vb.) ölçme değerlendirme çalışmaları tam olarak uygulanmıyor" (Öğretim Elemanı 5).

\section{Öğretmen Adayının Kısa Süreli Öğretmenlik Uygulamasının Okula Yansıması}

Öğretmen adaylarının haftada bir gün öğretmenlik uygulamasına gitmesinin okula uyumlarına, okulu benimsemelerine, diğer öğretmenlerle ilişkilerine, okul yönetimiyle ilişkilerine ne tür katkılar yaptığı merak konusudur. Öğretmen adaylarının, uygulama öğretmenlerinin, okul yöneticilerinin ve öğretim elemanlarının görüşlerine göre öğretmen adaylarının okula uyumlarıyla ilgili bulgular Tablo 7'de sunulmuştur.

Tablo 7

Ögretmen Adayının Okula Uyumuyla İlgili Bulgular

\begin{tabular}{lllll}
\hline Kodlar & $\begin{array}{l}\text { Öğretmen } \\
\text { Adayı }\end{array}$ & $\begin{array}{l}\text { Uygulama } \\
\text { Öğretmeni }\end{array}$ & $\begin{array}{l}\text { Okul } \\
\text { Yöneticisi }\end{array}$ & $\begin{array}{l}\text { Öğretim } \\
\text { Elemanı }\end{array}$ \\
\hline Okula uyum sağlıyor. & 4 & 1 & - & 4 \\
Okula uyum sağlamaya çalışıor. & 4 & 4 & 2 & 2 \\
Okula uyum sağlayamıyor. & - & - & 2 & 2 \\
\hline $\begin{array}{l}\text { Okulu benimsiyor. } \\
\text { Okulu kısmen benimsiyor. }\end{array}$ & 4 & 2 & - & 2 \\
$\begin{array}{l}\text { Okulu benimsemiyor. } \\
\text { Mesleğini benimsiyor. }\end{array}$ & - & - & 2 & 3 \\
Mesleğini kısmen benimsiyor. & 5 & 6 & 2 & 3 \\
\hline $\begin{array}{l}\text { Uygulama günü dışında da okula } \\
\text { gitmek ister. }\end{array}$ & 8 & 3 & 1 & 2 \\
$\begin{array}{l}\text { Uygulama günü dışında bazen okula } \\
\text { gitmek ister. }\end{array}$ & - & - & 2 & 5 \\
$\begin{array}{l}\text { Uygulama günü dışında okula gitmek } \\
\text { istemez. }\end{array}$ & - & 4 & 1 & - \\
$\begin{array}{l}\text { Uygulama günü dışında okula hiç } \\
\text { gitmez. }\end{array}$ & 8 & 4 & - & - \\
\hline
\end{tabular}


Öğretmen adayları, uygulama öğretmenleri ve öğretim elemanları öğretmen adaylarının okula uyumlarıyla ilgili hemen hemen benzer görüştedirler. Uyum sağladıklarını ya da çaba sarf ettiklerini düşünmektedirler. Okul yöneticilerinin yarısı ise okula uyum sağlayamadıklarını belirtmiştir. Öğretmen adaylarının yarısı ve öğretim elemanlarının çoğunluğu da okulu benimsediklerini düşünürken uygulama öğretmenlerinin çoğunluğu (6) ile yöneticilerin yarısı okulu benimsemediklerini düşünmektedirler. Mesleğe yönelik görüşleri ise kısmen yakındır ve mesleklerini benimsediklerini belirtmişlerdir. Öğretmen adayları uygulama günü dışında da okula gitmek istediklerini ancak hiç gitmediklerini ifade etmişlerdir. Uygulama öğretmenleri ve yöneticiler öğretmen adaylarının okula uygulama günü dışında gelmeye isteksiz olduklarını söylemişlerdir. Katılımcılar düşüncelerini şöyle açıklamışlardır:

"Uyum sağlamaya çalışıoruz diyebilirim. Okula aidiyet hissetmiyorum. Kendimi misafir gibi hissediyorum. Mesleğe aidiyet hissi zamanla artıyor" (Ö. Adayı $3)$.

"Okulu yeterince benimsemiyorlar. Dönüşümlü sınıflara girdiklerinde de hiçbir sınıfı benimsemiyorlar. Okula aidiyet hissettiklerini düşünmüyorum. Mesleğe yönelik ise öğrenciden öğrenciye değişiyor" (Öğretmen 5).

"Okula uyum sağlıyorlar, okula ait olduklarını hissetmiyorlar. Hemen gitme derdine düşüyorlar. Böyle bir gün gelmeyle öğretmen de olunmaz, öğretmen olarak da hissedilmez" (Yönetici 4).

"Okula uyum ilk birkaç hafta içinde oluşuyor. Ama haftada bir gün gitmekle okula aidiyet hissettiklerini düşünmüyorum. Mesleğe karşı aidiyet ise dönemin sonuna doğru oluşuyor" (Öğretim Elemanı 6).

Öğretmen adaylarının okulda geçirdikleri bu kısa süre içinde diğer öğretmenlerle kurdukları ilişkiler konusunda öğretmen adaylarının, uygulama öğretmenlerinin, okul yöneticilerinin ve öğretim elemanlarının düşünceleri doğrultusunda derlenen bulgular Tablo 8'de sunulmuştur.

Tablo 8

Öğretmen Adayının Diğer Öğretmenlerle İletişimine İlişsin Bulgular

\begin{tabular}{lllll}
\hline Kodlar & $\begin{array}{l}\text { Öğretmen } \\
\text { Adayı }\end{array}$ & $\begin{array}{l}\text { Uygulama } \\
\text { Öğretmeni }\end{array}$ & $\begin{array}{l}\text { Okul } \\
\text { Yöneticisi }\end{array}$ & $\begin{array}{l}\text { Öğretim } \\
\text { Elemanı }\end{array}$ \\
\hline İletişim kurabiliyor. & 6 & 3 & - & 3 \\
Çok az öğretmenle iletişim kuruyor. & 2 & 1 & 1 & 2 \\
İletişim kuramıyor. & - & 4 & 3 & 3 \\
\hline
\end{tabular}

Tablo 8'de görüldüğü gibi öğretmen adaylarının çoğunluğu (6) diğer öğretmenlerle iletişim kurabildiklerini söylemiştir. Uygulama öğretmenleri ve okul yöneticileri ise tersi yönde görüş bildirmiştir. Sadece dersine girdikleri öğretmenlerle 
iletişim kurduklarını ifade etmişlerdir. Öğretim elemanlarının da yarıdan fazlası öğretmen adaylarının iletişim kurabildiğini düşünmektedir. İletişim kuramamasını ya da az iletişim kurabilmesini de bazı okullarda öğretmen adaylarının öğretmenler odasına alınmamasıyla ilişkili olarak açıklamışlardır. Katılımcılar bu konudaki görüşlerini şu sözlerle paylaşmışlardır:

"Şuan bulunduğum staj okulunda bir öğretmen bizimle sıkı bir şekilde ilgileniyor. Kendi deneyimlerini, olması gerekeni ders sonu tartışmasında paylaşıyor ancak bir önceki staj okulumda böyle bir şey yoktu” (Ö. Adayı 1).

"Sınıflara dönüşümlü girdikleri için bütün öğretmenlerle iletişim kurabiliyorlar. Sadece uygulama yapacakları derslerle ilgili (hangi sınıflarsa) bilgi alışverişinde bulunuyorlar" (Öğretmen 5).

“Genelde sadece sınıfına girdikleri öğretmenlerle iletişim kuruyorlar. Ayrıca okulun fiziki imkânlarının sınırlı olması, öğretmenler odasının paylaşılamaması da bunda etkili”" (Öğretim Elemanı 5).

"Haftada bir gün gelindiği için staj onlar için bir zorunluluk. Bu yüzden okul öğretmenleriyle pek iletişim kurmuyorlar.” (Yönetici 4)

Öğretmen adaylarının günlük uygulamalarının iki saati okul yönetimi ile ilişkili devam ettirilmelidir. Hem okul yönetimi ile ilgili bilgilerin edinilmesi hem de bir öğretmen olarak okul yönetimiyle ilişkiler çok önemli olduğundan, öğretmen adaylarının okul yönetimiyle ilişkilerinin nasıl olduğunu görmek için sorulan sorudan elde edilen bulgular Tablo 9'da verilmiştir.

Tablo 9

Öğretmen Adayının Okul Yönetimiyle İletişimine İlişkin Bulgular

\begin{tabular}{lllll}
\hline Kodlar & Öğretmen & Uygulama & Okul & Öğretim \\
& Adayı & Öğretmeni & Yöneticisi & Elemanı \\
\hline Yeterince iletişim kuramıyor. & 2 & 5 & 3 & 4 \\
İyi iletişim kurabiliyor. & 4 & 2 & 1 & 3 \\
Müdür yardımcısıyla iletişim kuruyor. & 2 & 1 & - & 1 \\
\hline
\end{tabular}

Öğretmen adayları okul yönetimiyle ilgili bilgileri edinmek için bir ya da iki hafta öğleden sonraları (toplam dört saat) müdür yardımcısıyla görüşerek bilgi aldıklarını ifade etmişlerdir. Genel olarak iletişimleriyle ilgili olarak gereksinimleri olduğunda gidip görüşebildiklerini belirtmişlerdir. İki öğrenci yeterli bir iletişim olduğunu düşünmemektedir. Uygulama öğretmenlerinin (5) ve yöneticilerin (3) çoğunluğu ile öğretim elemanlarının da yarısı yeterince iletişim kuramadıklarını söylemişlerdir. Öğretmen adayının okul yönetimiyle iletişimine ilişkin katılımcıların ifadelerinden bazıları şöyledir:

"İhtiyacım olan konularda iletişim kuruyorum" (Ö. Adayı 7). 
“Müdür yardımcısıyla iletişim içinde oluyorlar” (Öğretmen 3).

"Kendilerinden sorumlu müdür yardımcısı ile iletişim kuruyorlar” (Öğretim Elemanı 2).

“Okul yönetimi ile iletişim sınırlı oluyor. Vakit bulamıyorlar. İmza atmak veya bazı sorunları dışında okulun idari işlerini öğrenmeleri için zaman ayırmalılar (ilk görev yerlerinde çok gerekli olabilir.)" (Yönetici 2).

Öğretmen adaylarının okul etkinliklerine destek vermeleri ya da daha genel anlamda okula katkıları olup olmadığına yönelik sorulan soruya verilen yanıtlar doğrultusunda oluşturulan kodlar ve bunların sıklıkları Tablo 10' da verilmiştir.

Tablo 10

Öğretmen Adayının Okula Katkısıyla İlişkili Bulgular

\begin{tabular}{llll}
\hline Kodlar & $\begin{array}{l}\text { Öğretmen } \\
\text { Adayı }\end{array}$ & $\begin{array}{l}\text { Uygulama } \\
\text { Öğretmeni }\end{array}$ & $\begin{array}{l}\text { Okul } \\
\text { Yöneticisi }\end{array}$ \\
\hline Okula katkısı olmuyor. & 5 & 5 & 1 \\
Birkaç öğretmen adayının katkısı oluyor. & 3 & 2 & 3 \\
Etkinliklere katılmak ister. & 7 & 4 & 2 \\
Etkinliklere katılmak istemez. & 1 & 4 & 2 \\
Etkinliklere katılan öğretmen adayı sayısı. & 1 & 2 & 2 \\
\hline
\end{tabular}

Öğretmen adaylarından iki kişi okula katkı yapacakları bir ortam olmadığından, bir kişi kendilerine fırsat sunulmadığından söz etmiştir. Öğretmen adaylarının (5) ve öğretmenlerin (5) yarıdan fazlası ise öğretmen adaylarının okula katkılarının olmadığını düşünüyor. Çoğunlukla etkinliklere katılmak istedikleri belirtilirken katılan sayısının bir ya da iki kişi olduğu görülmektedir. Katılımcıların konuya yönelik sözleri aşağıda verilmiştir:

"Bunun için bize fırsat tanınmıyor. Biz oradayken 'sadece size söyleneni yapın!' atmosferi var. Bizim bir şeyler yapmamıza izin vereceklerini sanmıyorum” (Ö. Adayı 5).

"Çok az da olsa oluyor. Belirli günler ile ilgili pano hazırlama, törenlerde gösteri hazırlama (1-2 öğrenci)" (Öğretmen 5).

"Okulun çevresinde bulunan fiziki mekânların kullanımında, okul bahçesinin temizliğinde, çocukların aileleriyle iletişimde, belirli gün ve haftalarla ilgili panoların hazırlanmasında katkıları oluyor" (Yönetici 1).

Öğretmen Adayının Kısa Süreli Öğretmenlik Uygulamasının Yeterliğine İlişkin Görüşler

Öğretmen adaylarının haftada bir gün öğretmenlik uygulamasına gitmesinin sınıf içine ve okula nasıl yansıdığı betimlendikten sonra bu uygulama süresinin yeterliğine ilişkin öğretmen adaylarının, uygulama öğretmenlerinin, okul 
yöneticilerinin ve öğretim elemanlarının görüşleri alınmıştır. Elde edilen bulgular Tablo 11'de sunulmuştur.

Tablo 11

Haftada Bir Gün Uygulama Yapmanin Yeterliğine İlişkin Bulgular

\begin{tabular}{lllll}
\hline Kodlar & $\begin{array}{l}\text { Öğretmen } \\
\text { Adayı }\end{array}$ & $\begin{array}{l}\text { Uygulama } \\
\text { Öğretmeni }\end{array}$ & $\begin{array}{l}\text { Okul } \\
\text { Yöneticisi }\end{array}$ & $\begin{array}{l}\text { Öğretim } \\
\text { Elemanı }\end{array}$ \\
\hline Bir gün yeterli değil. & 8 & 7 & 4 & 6 \\
Yeterli . & - & - & - & 2 \\
Kismen yeterli. & 2 & 1 & - & - \\
Uygulama geliştiriyor. & 3 & - & - & - \\
\hline
\end{tabular}

Haftada bir gün öğretmenlik uygulaması yapmanın yeterliği konusunda katılımcıların neredeyse tamamı uygulama süresinin yetersiz olduğunu düşünmektedir. Sadece iki öğretim elemanı sürenin yeterli olduğunu ifade etmiştir. Katılımcıların bu konudaki önerileri [öğretmen adayı (5), öğretmen (4), yönetici (3) ve öğretim elemanı (5)] ise uygulama süresinin daha uzun olması gerektiği yönündedir. Ayrıca öğretmen adaylarının ikisi, okul uygulamalarının fakülteye başladıkları ilk yıldan itibaren olması gerektiğini söylemişlerdir. Haftada bir gün uygulama yapmanın yeterliği konusunda katılımcıların sözleri şöyledir:

Şöyle ki öğretmenlik uygulaması bir öğretmen adayı için mesleği en iyi anladığı, öğrendiği yerdir. Bunun sebebi ise yaşayarak öğrenme dediğimiz kavramdır. Sadece bir gün olması öğretmen adayının öğrenme ve anlama gibi şeyleri yeterli olarak yapamaması demektir. Ben bir gün yeterli olmadığı için öğrencilerin karşısında çok fazla geriliyorum. (Ö. Adayı 1)

"Yeterli olduğunu düşünmüyorum. En azından bir hafta her gün okula gelerek okulun işleyişini, sınıfta bir hafta boyunca yapılanları gözlemlemelerinin yararlı olacağını düşünüyorum" (Öğretmen 5).

"Yeterli değil. Uygulamaların 4. sınıfta değil, 1. Sınıftan itibaren kademe kademe verilmesi gerekir. Teori ile uygulamanın birleştiği öğrenme ortamlarının oluşması şart" (Öğretim Elemanı 4).

"Öğrencilerin, öğretmenlik deneyimi kazanmaları açısından bir günlük süre yetersizdir" (Yönetici 4).

Son araştırma sorusu kapsamında farklı bir uygulama oluşturabilmek için alanyazın ve ülkelere ait resmi sitelerin verilerine bağlı olarak oluşturulan diğer ülkelerin okul uygulama sistemleri ile ilgili karşılaştırma yapılmıştır. Finlandiya, Singapur özellikle son dönemde eğitimleriyle ilgili başarılı bir tablo sundukları için, Almanya ise en uzun süre öğretmenlik uygulaması yapan ülke olduğu için seçilmiştir. Karşılaştırma bulguları Tablo 12'de verilmiştir. 
Tablo 12

Türkiye ve Bazı Ülkelerin Öğretmenlik Uygulaması Karşılaştırması

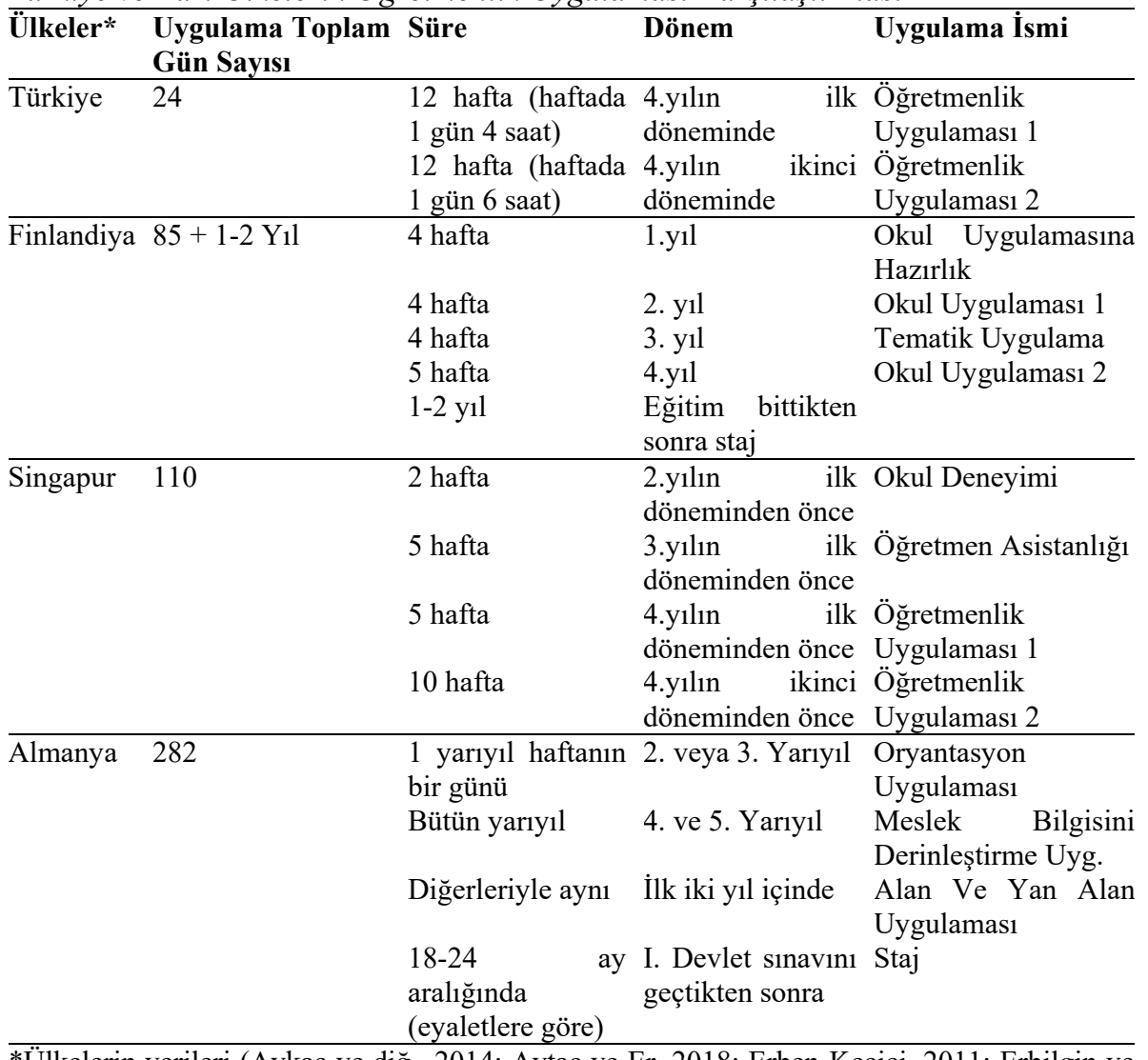

*Ülkelerin verileri (Aykaç ve diğ., 2014; Aytaç ve Er, 2018; Erben-Keçici, 2011; Erbilgin ve Boz, 2013; Göçen-Kabaran ve Görgen, 2016; Kansanen, 2003; National Institute of Education Singapore-NIE, 2019; Niemi ve Jakku-Sihvonen, 2011; YÖK, 2018).

Finlandiya, Singapur ve Almanya'da öğretmenlik uygulaması, birinci ya da ikinci yıldan başlayarak tüm öğretmenlik eğitimi sürecine yayılmıştır. Uygulamanın olanaklı olduğu kadar erken başlaması ve kuramsal çalışmalarla uygulamanın bütünleşmesi sağlanmaya çalışılmaktadır. İlk dönem uygulamaları öğretmen adaylarına okul yaşamını ve öğrencileri eğitim bakış açısıyla gözlemleme konusunda rehberlik etmektedir. Sonraki dönemlerdeki uygulamalar ise öğretmen adaylarına kuramsal bilgilerle uygulamayı bütünleștirme olanağı sunmaktadır. Son dönem uygulamalarında ise öğretmen adayından sınıf ve okulla ilgili bütün sorumluluğu almaları beklenmektedir. Türkiye ile diğer ülkeler karşılaştırıldığında, okul uygulamaları için Türkiye'de daha az süre ayrıldığı, daha az ders olduğu ve okul 
uygulamasının bütün eğitim süresine yayılmadığı, lisans öğretiminin sadece son yılına bırakıldı̆̆ı görülmektedir.

\section{Tartışma, Sonuç ve Öneriler}

Bu çalışmada bir öğretmen adayının yetiştirilmesi sırasında kuramsal bilgilerinin uygulamaya dönüştürüldüğü öğretmenlik uygulamalarının haftada bir gün olmasının yeterli olup olmadığ 1 ile ilgili öğretmen adaylarının, uygulama öğretmenlerinin, okul yöneticilerinin ve öğretim elemanlarının görüşleri ortaya çıkarılmıştır. Sonrasında Türkiye, Finlandiya, Singapur ve Almanya'daki öğretmen yetiştirme sürecinde uygulanan öğretmenlik uygulamaları gün, ders sayısı, uygulama dönemleri açısından karşılaştırılmıştır. Öğretmenlik uygulaması dersinin bileşenlerinden 28 kişiden veri toplanmıştır. Bu veriler doğrultusunda aşağıdaki sonuçlara ulaşılmıştır:

Öğretmen adaylarının, uygulama öğretmenlerinin, okul yöneticilerinin ve öğretim elemanlarının görüşlerine göre haftada bir gün öğretmenlik uygulamasına giden öğretmen adaylarının çoğunlukla sınıflarındaki çocukları tanımadıkları ortaya çıkmıştır. Özmen (2008) tarafından yapılan çalışmaya göre de öğretmen adayları, farklı düzeydeki öğrencilere nasıl davranılacağını bilemediklerini, öğrencilerle bireysel ya da grup olarak çalışma olanağı bulamadıklarını dile getirmişlerdir. Oysa öğrencilerin her biri birbirinden farklıdır. Öğretmenin bu bireysel farklılıkları bilip öğrenme ortamını buna göre düzenlemesi gerekir.

Öğretmen adaylarının eğitimleri sırasında öğrencilerle doğru iletişim kurabilmesi de önemli öğelerden biridir. Kendilerinden öğrenciye yönergeler sunma, açık cümleler kurma, öğrencinin içinde bulunduğu duruma uygun davranabilme, öğrenciden ne istediğini söyleyebilme gibi iletişim becerileri geliştirmeleri beklenmektedir. Yapılan çalışmada hem öğretmen adaylarının hem de diğer bileşenlerin çoğunluğuna göre adayların öğrencilerle ya iletişim kuramadığı ya da kısmen kurabildiği ortaya çıkmıştır. Akpınar, Çolak ve Yiğit'in (2012) çalışmasında da uygulama öğretmenlerinin öğretmen adaylarında en yetersiz gördükleri özelliğin iletişim becerilerinin eksikliği olduğu bulgusuna ulaşılmıştır. Karasu-Avcı ve İbret (2016) öğretmen adaylarının karşılaştıkları problemleri sıralarken öğrencilerle iletişimde sorunların olduğunu ve sınıf yönetiminde zorlandıklarını belirtmektedir. $\mathrm{Bu}$ veriler çalışmayı desteklemektedir. Ancak alanyazında tam tersi sonuca ulaşan çalışmalar da vardır. Örneğin Karadüz, Eser, Şahin ve İlbay’ın (2009) yaptığı çalışmada öğretmen adaylarının uygulama okullarındaki öğrencilerle rahat iletişim kurabildiği ortaya çıkmıştır. Bu durum çalışma grubundan kaynaklanabilmektedir.

Araştırmada öğretmen adaylarının sınıf yönetimi becerilerinin de istenilen düzeyde olmadığı ortaya çıkmıştır. Karadüz ve diğ.'nin (2009) çalışmasında öğretmen adaylarının öğretmenlik uygulamasının sonunda bazı sınıf yönetimi becerilerini sergilerken derse uygun bir giriş yapabilme, ilgi ve dikkati çekebilme, ödül / cezayı kullanabilme, uygun ödevler verebilme ve sınıftan çıkmaya hazırlayabilme yeterliklerinin yeterince gelişmediğini ortaya koymuştur. Akpınar ve diğ. (2012) de çalışmasında uygulama öğretmenlerinin düşüncelerine göre öğretmen adaylarının 
sınıf yönetimi becerilerinin düşük olduğunu ortaya çıkarmıştır. Baştürk (2009) çalışmasında öğretmen adaylarının hem ders anlatımı öncesinde hem de anlatım sırasında yaşadıkları kaygıların başında sınıf yönetiminin geldiğini ifade etmektedir. Benzer biçimde Altıntaş ve Görgen (2014) de çalışmasında öğretmen adaylarının yaşadıkları güçlüklerin başında sınıf yönetimini sağlamak olduğunu dile getirmişlerdir.

Uygulama öğretmenlerinin ve öğretim elemanlarının yarıdan fazlası öğretmen adaylarının etkili öğrenme ortamı oluşturmadığını düşünmektedirler. Öğretmen adaylarının da yarısı kısmen oluşturabildiklerini düşünmektedir. Karadüz ve diğg. (2009) öğretmenlik uygulamasına katılan öğretmen adaylarının uygulama sonrasında adayların gelişimine katkı sağladığını fakat öğretim yöntem ve tekniklerini kullanabilme, özetleme ve uygun dönütler verebilme yeterliklerinde herhangi bir değişmenin olmadığını ortaya koymuştur. Akpınar ve diğ. (2012) uygulama öğretmenlerinin, öğretmen adaylarının öğrenme ortamı konusunda çok yeterli olmadığını ve deneyimsiz olduklarını düşündüğünü ortaya çıkarmıştır. Alanyazındaki bu çalışmalar araştırma sonuçlarıyla uyumludur.

Öğretmen adayları ölçme değerlendirme etkinliklerini, anlattıkları ders kapsamında yapmaktadır. Genel ölçme değerlendirme etkinliklerine katılmamışlardır. Yaman ve Karamustafaoğlu'nun (2011) yaptı̆̆ı çalışmaya göre öğretmen adayları ölçme değerlendirme etkinlikleri kapsamında kendilerini çok yeterli görmemektedirler. Bu yetersizlik durumunu fakültede bu dersi kuramsal olarak almalarına bağlamışlardır. $\mathrm{Bu}$ kapsamda öğretmenlik uygulaması süresinin artırılması, öğretmen adaylarının kuramsal bilgilerini uygulamaya dönüştürmelerini sağlayacaktır. Alanyazında bu sonuçları desteklemeyen bulgular da vardır. Akpınar ve diğ. (2012) uygulama öğretmenlerinin, öğretmen adaylarının ölçme değerlendirme etkinliklerinde yeterli düzeyde olduklarını düşündüklerini ortaya çıkarmıştır.

Öğretmen adaylarının okula uyum sağlamaya çalıştıkları, okulu benimsemedikleri, mesleklerini de benimsemenin zamanla geliştiği düşünülmektedir. Ayrıca öğretmen adaylarının uygulama günü dışında okula hiç gitmedikleri de görülmektedir. Becit ve diğ. (2009) çalışmasında okul uygulamalarının öğretmen adaylarının mesleğe yönelik algılarını olumlu etkilediğini ortaya koymuştur. Altıntaş ve Görgen'in (2014) çalışmasında da öğretmen adayları öğretmenlik uygulaması dersiyle mesleğe uygun olup olmama noktasındaki kararlarını belirlediklerini belirtmişlerdir. Çetintaş ve Genç'in (2005) çalışmasına göre öğretmenlik uygulamasından sonra öğretmen adaylarının yarıdan fazlası mesleğe yönelik olumlu düşüncelere sahip olduğunu dile getirmiştir. Öğretmenlik uygulaması dersi kuramsal bilginin uygulamaya dönüşmesini sağladığı gibi öğretmen adaylarının mezun olduklarında yapacakları işi deneyimlemesini de sağlamaktadır. Eğitim fakültesini puanı yettiği, iş olanağı sunduğu, çevresinin yönlendirdiği gibi nedenlerle (Erdoğan, Şanlı ve Şimşek-Bekir, 2005; Gürbüz ve Kışoğlu, 2007) seçen öğrencilerin öğretmenlik mesleğine uygun olup olmadığını anlaması, mesleğin benimsenmesi açısından gereklidir. Öğretmenlik uygulamasının bir günle sınırlı olması durumunda 
okula uyum, aidiyet gelişmesi çok zordur. Çünkü okulun benimsenmesi, okuldaki öğretmenler ve diğer öğrencilerle olan etkileşimlerden etkilenen bir kavramdır (Sarı, 2013).

Öğretmen adayının okul kültürünü kavrayabilmesi için öğretmenlerle iletişim içinde olması gereklidir. Araştırma bulgularına göre öğretmen adayları sınıfina girecekleri öğretmenle iletişim kurmaktadır. Ancak bu iletişim anlatacakları konu, neler yapılması gerektiği ya da önerilerle sinırlıdır. Öğretmen adayları öğretmenler odasını kullanmamakta, okulla ilgili ya da eğitim öğretimle ilgili genel işleyişe katılmamaktadır. Çetintaş ve Genç (2005) çalışmasında öğretmen adaylarının yarısının öğretmen odasını kullandığını, \% 30'unun çekindiğini, geriye kalanların ise hiç kullanmadığını ortaya çıkarmıştır. Bununla birlikte öğretmen adaylarının \% 40'ının diğer öğretmenlerle tanışmadığını da dile getirmiştir. Okul içindeki çalışanların davranışlarını yönlendiren normlar, değerler, alışkanlıklar iletişim kurulmadan nasıl öğrenilebilir? Bu nedenle öğretmen adaylarının öğretmenlerle iletişimi sadece ders kapsamıyla sınırı kalmamalıdır.

Öğretmen adaylarının okul yönetimiyle iletişimlerinde de benzer durum ortaya çıkmıştır. Öğretmen adaylarının gereksinimleri doğrultusunda görevli müdür yardımcısıyla iletişime geçtikleri, bunun dışında paylaşımda bulunmadıkları ortaya çıkmıştır. Çetintaş ve Genç (2005) çalışmasında 30 öğretmen adayının \% 60'ının okul yöneticileriyle sınırlı iletişim kurduğunu, \% 40'ının ise sadece tanıştırıldığını ortaya çıkarmıştır. Zembat, Tunçeli ve Akşin (2015) çalışmasında öğretmen adaylarının okul yöneticisini lider, yol gösterici, problem çözen ve okul için vazgeçilmez kişi olarak tanımladıklarını ortaya çıkarmıştır. Öğretmen adaylarının okul yöneticisi algılarının olumlu olması, yöneticilerin yapacağı mentörlükten de yararlanmaya açık olmalarını sağlayacaktır. Okul yöneticilerinin mentörlük rolleri gereği öğretmen adayları ile uzun süreli etkileşim içinde olmaları gerekmektedir. $\mathrm{Bu}$ durum bireyler arasında duygusal destek sağlayacağı gibi işe yönelik mesleki yardım da sağlamaktadır (Sezgin, Koşar ve Er, 2014).

Araştırmada öğretmen adaylarının okula fazla katkılarının olmadığı ve okul etkinliklerine katılmadıkları görülmektedir. Çetintaş ve Genç (2005) öğretmen adaylarının sadece \% 20'sinin okul gezisi, idari işler, bayrak töreni, nöbetçi öğretmenlik gibi ders dışı sorumluluklar üstlendiğini ortaya koymuştur. Bu sonuçlar araştırma sonuçlarını destekler niteliktedir. Öğretmen adaylarının öğretmenlik rolünü iyice benimsemeleri, okulu ve mesleği benimsemeleri için okulda yapılan etkinliklere de katılmaları, öğrencilerle ve öğretmenlerle etkili iletişim kurarken okulun bir üyesi olarak okula katkı sağlamaları gerekmektedir. Bu, öğretmen adayının iş üstünde yetişmesi kapsamında gerekli bir yaşantıdır.

Araştırmaya katılan öğretmen adaylarının, uygulama öğretmenlerinin, okul yöneticilerinin ve öğretim elemanlarının çoğunluğu öğretmenlik uygulamasını süre olarak yeterli görmemektedirler. Karadüz ve diğ. (2009) yaptıkları çalışmanın sonucunda öğretmen adaylarının uygulama ortamlarından (okul) yeterince etkilenmediklerini ortaya koymaktadır. Eraslan (2009) araştırmasında öğretmen 
adaylarının istenilenleri tam olarak yerine getirme noktasında yeteri kadar firsat bulamadığını ortaya koymuştur. Akpınar ve diğ. (2012) öğretmen adaylarının bazı konularda yetersiz olmalarını okullarında geçirdikleri sürenin çok kısıtlı olmasına bağlamaktadırlar. Gökçe ve Demirhan (2005) tarafından yapılan çalışmada hem uygulama öğretmenleri hem de öğretmen adayları öğretmenlik uygulamasının daha uzun süreli olması gerektiğini belirtmiştir. Aslan ve Sağlam (2018) çalışmasında öğretmen adaylarının öğretmenlik uygulamasının son dört döneme yayılması gerektiğini ve var olan durumun yetersizliğini söylemişlerdir. Karasu-Avcı ve İbret (2016) araştırmasının sonunda öğretmenlik uygulaması derslerinin ilk sınıflardan itibaren başlaması gerektiğini tartışmaya açmıştır. Öğretmenlik uygulaması ile ilgili alanyazında yapılan çalışmaların çoğunda öğretmenlik uygulaması süresinin yetersizliğine değinilmiştir (Altıntaş ve Görgen, 2014; Şaşmaz-Ören, Sevinç ve Erdoğmuş, 2009; Şimşek, Alkan ve Erdem, 2013).

Araştırmada son olarak Türkiye, Finlandiya, Singapur ve Almanya'da öğretmen yetiştirme kapsamında okul uygulamaları karşılaştırılmıştır. Türkiye'de 2018-2019 öğretim yılından itibaren uygulanan yeni lisans programlarına göre bütün öğretmenlik alanlarında son sınıfın iki döneminde 12'şer günden toplam 24 gün öğretmenlik uygulaması yaptırılmaktadır. Finlandiya'da öğretmenlik uygulaması öğretmen yetiştirme programlarının ilk yılından itibaren başlamakta ve eğitim süresinde dört uygulama yapılmaktadır. Singapur'da da öğretmenlik uygulaması ikinci yıldan önce başlamakta ve Finlandiya'da olduğu gibi dört ayrı uygulama bulunmaktadır. Almanya'da da yine birinci yıldan başlamakta ve dört uygulama bulunmaktadır. Almanya diğer ülkeler arasında en fazla gün (282) öğretmenlik uygulaması yaptıran ülkedir. Türkiye dışında diğer ülkelerin bütün eğitim süreci boyunca öğretmenlik uygulaması yaptırdıkları ve son dönemde belli bir süre boyunca uygulama sınıfının tamamen öğretmen adayına bırakıldığı görülmüştür.

Araştırmada öğretmenlik uygulamasının süresiyle ilgili yetersizlik ortaya konmaya çalışılmıştır. Türkiye'de öğretmenlik uygulamasının yeniden düzenlenmesi gerekmektedir. Araştırma kapsamında farklı bir uygulama önerilmiştir. Önerilen uygulama dersleri, dönemleri ve süreleri Tablo 13'te sunulmuştur.

Öğretmen yetiştirme lisans programlarına göre teorik pedagoji dersleri (Öğretim İlke ve Yöntemleri, Sınıf Yönetimi, Öğrenme ve Öğretim Yaklaşımları, Türk Eğitim Sistemi ve Okul Yönetimi vb.) ikinci sınıftan itibaren başlamaktadır (YÖK, 2018). Bu derslerin de uygulamada nasıl yapıldığını görmeleri bakımından ilk uygulama ikinci sınıfta üçüncü dönemde gözlem amaçlı gerçekleştirilebilir. İkinci uygulama ise bu kuramsal derslerin uygulamaya dönüşmesi şeklinde üçüncü sinıfta beşinci dönemde tematik olarak uygulanabilir. Üçüncü uygulama dördüncü sınıfta yedinci dönemde ve bir günlük sorumluluk şeklinde Öğretmenlik Uygulaması I olarak uygulanabilir. Son uygulama ise dördüncü sınıfın son yarıyılında öğretmen adayı bütün bir dönemi uygulama okulunda geçirebilir. 
Tablo 13

Önerilen Uygulama Dersleri, Dönemleri ve Süreleri

\begin{tabular}{llll}
\hline Dönem & Uygulama ismi & Süre & Toplam süre \\
\hline $\begin{array}{l}\text { İkinci sı̈nf } \\
\text { Üçüncü dönem }\end{array}$ & Gözlem & 12 hafta (haftada 1 gün 4 saat) & 12 gün \\
\hline $\begin{array}{l}\text { Üçüncü sınıf } \\
\text { Beşinci dönem }\end{array}$ & Tematik & 12 hafta (haftada 1 gün 4 saat) & 12 gün \\
\hline $\begin{array}{l}\text { Dördüncü sınıf } \\
\text { Yedinci dönem }\end{array}$ & Öğretmenlik & 12 hafta (haftada 1 gün 6 saat) & 12 gün \\
\hline $\begin{array}{l}\text { Dördüncü sınıf } \\
\text { Sekizinci dönem }\end{array}$ & $\begin{array}{l}\text { Öğretmenlik } \\
\text { Uygulaması II }\end{array}$ & $\begin{array}{l}\text { 12 hafta (haftada 5 gün/ sadece } \\
\text { uygulama okulunda) }\end{array}$ & 60 gün \\
\hline
\end{tabular}

Öğretmen adayının bütün bir dönemi uygulama okulunda geçirmesi Köy Enstitülerinde uygulanmıştır. Ayrıca 2016 yılında atanan aday öğretmenler, altı aylık okullarda yetiştirme programına alınarak stajyerlik eğitimlerine başlamışlardır. Bu program sadece bir kere uygulanmıştır. Çam-Tosun ve Şimşek (2018) tarafindan yapılan çalışmada, okullardaki yetiştirme programının atanan öğretmenler için zorlayıcı olduğu (öğrencilerle ve diğer öğretmenlerle ilişkilerde sıkıntılar, eğitim öğretim etkinliklerinden çok formalite için yapılan evrak işleri ya da tam zamanlı öğretmen olamamaları) ve bu uygulamanın zaman olarak yanlış olduğu ve üniversite eğitimleri sırasında yapılması gerektiği sonucuna ulaşmıştır. 2016 yılında aday öğretmenler için tasarlanan yetiştirme eğitimi, öğretmenlik programlarının son döneminde uygulanabilir. Son dönem fakültede alınan dersler önceki dönemlere kaydırılıp her öğretmen adayına bir rehber öğretmen atanarak bütün bir dönemi okullarda uygulama ile geçirmeleri sağlanabilir.

Sonuç olarak bu araştırmada öncelikle öğretmen adaylarının, uygulama öğretmenlerinin, okul yöneticilerinin ve öğretim elemanlarının görüşlerine göre, sonra da Türkiye, Finlandiya, Singapur ve Almanya öğretmen yetiştirme programlarındaki okul uygulama sistemlerinin karşılaștırılmasına göre Türkiye'de uygulanan okul uygulamalarının yetersizliği ortaya konmuştur. Bu yetersizliği giderebilmek için de Türkiye'de uygulanabilecek bir okul uygulamaları sistemi önerilmiştir.

\section{Kaynakça}

Ağanoğlu, H. (1949). Köy enstitüleri yolunda. İstanbul: Ahmet Sait Basımevi.

Akdemir, A. S. (2013). Türkiye'de öğretmen yetiştirme programlarının tarihçesi ve sorunlar1. Turkish Studies-International Periodical For The Languages, Literature and History of Turkish or Turkic, 8(12), 15-28.

Akpınar, M., Çolak, K. ve Yiğit, E., Ö. (2012). Öğretmenlik uygulaması dersi kapsamında sosyal bilgiler öğretmen adaylarının yeterliklerine yönelik uygulama öğretmenlerinin görüşleri. M. Ü. Atatürk Ĕ̆itim Fakültesi Ĕ̆itim Bilimleri Dergisi, (36), 41-67. 
Altıntaş, S. ve Görgen, İ. (2014). Sınıf öğretmeni adaylarının öğretmenlik uygulaması üzerine görüşleri (Muğla Sıtk1 Koçman Üniversitesi örneği). Turkish Studies International Periodical For The Languages, Literature and History of Turkish or Turkic, 9(8), 197-208.

Aras, S. ve Sözen, S. (2012, Haziran). Türkiye, Finlandiya ve Güney Kore'de ögretmen yetiştirme programlarının incelenmesi. X. Ulusal Fen Bilimleri ve Matematik Eğitimi Kongresinde sunulan sözlü veya poster bildiri, Niğde. Özet http://kongre.nigde.edu.tr/xufbmek/dosyalar/tam_metin/pdf/2527-31_05_201211_40_01.pdf adresinden edinilmiştir.

Arıkan, Y., D. (2009). Bilişim teknolojileri öğretmen adayları ve öğretmenlik uygulaması dersi. Ege Eğitim Dergisi, 10(1), 1-23.

Aslan, M. ve Sağlam, M. (2018). Öğretmenlik uygulaması dersinin öğretmen adaylarının görüşlerine göre değerlendirilmesi. Hacettepe Üniversitesi Eğitim Fakültesi Dergisi 33(1), 144-162, doi: 10.16986/HUJE.2017030313

Atanur-Baskan, G., Aydın, A. ve Madden, T. (2006). Türkiye'deki öğretmen yetiştirme sistemine karşılaştırmalı bir bakış, Ç. Ü. Sosyal Bilimler Enstitüsü Dergisi, 15(1), 35-42.

Aykaç, N., Kabaran, H. ve Bilgin, H. (2014). Türkiye'de ve bazı Avrupa Birliği ülkelerindeki öğretmen yetiştirme uygulamalarının karşılaştııılmalı olarak incelenmesi. Turkish Studies International Periodical For The Languages, Literature and History of Turkish or Turkic, 9(3), 279-292.

Aytaç, A. ve Er, K. O. (2018). Türkiye'de ve Finlandiya'da hizmet öncesi sınıf öğretmeni yetiştirme programlarındaki öğretmenlik uygulamalarının karşılaş̧ırılması. Eğitim Kuram ve Uygulama Araştırmaları Dergisi, 4(2), 1019.

Azar, A. (2003). Okul deneyimi ve öğretmenlik uygulaması derslerine ilişkin görüşlerinin yansımaları. Milli Ĕgitim Dergisi, (159), 181-194.

Baştürk, S. (2009). Öğretmenlik uygulaması dersinin öğretmen adaylarının görüşlerine göre incelenmesi, İlköğretim Online, 8(2), 439-456.

Becit, G., Kurt, A., A. ve Kabakçı, I. (2009). Bilgisayar öğretmen adaylarının okul uygulama derslerinin yararlarına ilişkin görüşleri. Anadolu Üniversitesi Sosyal Bilimler Dergisi, 9(1), 169-184.

Bilir, A. (2011). Türkiye'de öğretmen yetiştirmenin tarihsel evrimi ve istihdam politikaları. Ankara Üniversitesi Eğitim Bilimleri Fakültesi Dergisi, 44(2), 223246. 
Cirit-Gül, A . (2016). Türkiye ile Çin, Finlandiya, Japonya ve Hollanda'nın öğretmen yetiştirme ve seçme sistemlerinin karşılaştırılması. Adnan Menderes Üniversitesi Eğitim Fakültesi Eğitim Bilimleri Dergisi, 7(2), 63-72.

Çam-Tosun, F., and Şimsek, M. (2018). Candidate teacher education program confusion in Turkey. European Journal of Educational Research. 7(2), 407-419. doi: 10.12973/eu-jer.7.2.407

Çetintaş, B. ve Genç, A. (2005). Almanca öğretmen adaylarının öğretmenlik uygulaması derslerine ilişkin görüş ve deneyimleri. Hacettepe Üniversitesi Eğitim Fakültesi Dergisi, 29, 75-84.

Denzin, N., K., and Lincoln, Y., S. (2005). The Sage handbook of qualitative research ( $3^{\text {rd }}$ Ed.). Thousand Oaks, CA: Sage Publications.

Eraslan, A. (2009). İlköğretim matematik öğretmen adaylarının “öğretmenlik uygulaması” üzerine görüşleri. Necatibey Eğitim Fakültesi Elektronik Fen ve Matematik Eğitimi Dergisi 3(1), 207-221.

Erben-Keçici, S. (2011). Almanya'da öğretmen eğitimi. M. Ü. Atatürk Ĕ̆itim Fakültesi Eğitim Bilimleri Dergisi, 34, 117-132.

Erbilgin, E. ve Boz, B. (2013). Matematik öğretmeni yetiştirme programlarımızın Finlandiya, Japonya ve Singapur programları ile karşılaştırması [Özel Sayı]. Hacettepe Üniversitesi Eğitim Fakültesi Dergisi, 156-170.

Erdem, A., R. (2015). Türkiye'deki öğretmen yetiştirmenin a, b, c'si. Journal of Teacher Education and Educators, 4(1), 16-38.

Erdoğan, S., Şanlı, H. S. ve Şimşek-Bekir, H. (2005). Gazi üniversitesi, eğitim fakültesi öğrencilerinin üniversite yaşamına uyum durumları. Kastamonu Ĕ̆itim Dergisi, 13(2), 479-496.

Ergun, M. ve Ersoy, Ö. (2014). Hollanda, Romanya ve Türkiye'deki sınıf öğretmeni yetiştirme sistemlerinin karşılaştırılması. Kastamonu Eğitim Dergisi, 22(2), 673700 .

Eurydice-Informationsnetz zum Bildungswesen in Europa, (2009). Der lehrberuf in Europa: Profil, tendenzen und anliegen. bericht I. Lehrerausbildung und maßnahmen für den umgang in das berufleben. Allgemeinbildender sekundarbereich I. Brüksel: Eurydice.

Göçen-Kabaran G. ve Görgen, İ. (2016). Güney Kore, Hong Kong, Singapur ve Türkiye'deki öğretmen yetiştirme sistemlerinin karş1laştırmalı olarak incelenmesi, Bartın Üniversitesi Eğitim Fakültesi Dergisi, 5(2), 478-495. doi: 10.14686/buefad.v5i2.5000171265 
Gökçe, E. ve Demirhan C. (2005). Öğretmen adaylarının ve ilköğretim okullarında görev yapan uygulama öğretmenlerinin öğretmenlik uygulaması etkinliklerine ilişkin görüşleri. Ankara Üniversitesi Eğitim Bilimleri Fakültesi Dergisi, 38(1), 43-71.

Gürbüz, H., and Kışoğlu, M. (2007). Attitudes of the science and art faculty students and education faculty students attend the non- thesis graduated education program toward teaching profession (Atatürk University sample). Erzincan Üniversitesi Eğitim Fakültesi Dergisi, 9(2), 71-83. Retrieved from http://dergipark.gov.tr/erziefd/issue/6007/80090

Kansanen, P. (2003). Teacher education in Finland: Current models and new developments. In B. Moon, L. Vlãsceanu, and C. Barrows (Eds.), Institutional approaches to teacher education within higher education in Europe: Current models and new developments (pp. 85-108). Bucharest: UNESCO.

Karadüz, A., Eser, Y., Şahin, C. ve İlbay, A. B. (2009). Eğitim fakültesi son sınıf öğrencilerinin görüşlerine göre öğretmenlik uygulaması dersinin etkililik düzeyi. Mustafa Kemal Üniversitesi Sosyal Bilimler Enstitüsü Dergisi, 6(11), 442-455.

Karasu-Avc1, E. ve İbret, B. Ü. (2016). Öğretmenlik uygulaması-II dersine ilişkin okul öncesi öğretmen adaylarının görüşlerinin değerlendirilmesi. Kastamonu Eğitim Dergisi, 24(5), 2519-2536.

Merriam, S. B. (2013). Nitel araştırma desen ve uygulama için bir rehber [Qualitative research: A guide to design and implementation]. (S. Turan, Çev. Ed.). Ankara: Nobel Yayınları. (Orijinal kitabın yayım tarihi 2009)

Mete, Y.A. (2013). Güney Kore, Japonya, Yeni Zelanda ve Finlandiya' da öğretmen yetiştirme ve atama politikaları. Turkish Studies - International Periodical For The Languages, Literature and History of Turkish or Turkic, 8(12), 859-878.

Miles, B,. M., and Huberman, A., M. (1994). Qualitative data analysis. Thousand Oaks, CA: Sage Publications.

Milli Eğitim Bakanlığı (2018). Öğretmenlik uygulaması yönergesi. Tebliğler Dergisi, 81(2729), 2000-2017. http://oygm.meb.gov.tr/meb_iys_dosyalar/2018_06/25172143_YYnerge.pdf adresinden edinilmiştir.

National Institute of Education Singapore (2019). Undergraduate programmes. Retrieved from https://www.nie.edu.sg/teacher-education/practicum/practicumstructure/undergraduate-programmes

Niemi, H., and Jakku-Sihvonen, R. (2011). Teacher education in Finland. In M. Valencic-Zuljan and J. Vogrincin (Eds.), European dimensions of teacher education - similarities and differences (pp. ??-??). Slovenia: Dravska tiskarna 
The Organisation for Economic Co-operation and Development (2014). Education at a glance 2014: OECD indicators. OECD publishing. doi: 10.1787/eag-2014-en

Özmen, H. (2008). Okul deneyimi - I ve okul deneyimi -II derslerine ilişkin öğretmen adaylarının görüşleri. Ondokuz Mayıs Üniversitesi Eğitim Fakültesi Dergisi, 25, 25-37.

Özkılıç, R, Bilgin, A. ve Kartal, H. (2008). Öğretmenlik uygulaması dersinin öğretmen adaylarının görüşlerine göre değerlendirilmesi. İlköğretim Online, $7(3), \quad 726-737 . \quad$ Retrieved from http://dergipark.gov.tr/ilkonline/issue/8600/107092

Sarı, M. (2013), Lise öğrencilerinde okula aidiyet duygusu. Anadolu Üniversitesi Sosyal Bilimler Dergisi, 13(1), 147-160.

Sezgin, F., Koşar, S. ve Er, E. (2014). Okul yöneticisi ve öğretmen yetiştirmede mentörlük sürecinin incelenmesi. Kastamonu Eğitim Dergisi, 22(3), 1337-1356.

Silverman, D. (2005). Doing qualitative research ( $2^{\text {th }}$ Ed.). Thousand Oaks, CA: Sage Publications.

Şaşmaz-Ören, F., Sevinç, Ö. S. ve Erdoğmuş, E. (2009). Öğretmen adaylarının okul deneyimi derslerine yönelik tutumlarının ve görüşlerinin değerlendirilmesi. Kuram ve Uygulamada Ĕ̈itim Yönetimi Dergisi, 15(2), 217-246.

Şimşek, S., Alkan, V. ve Erdem, A. R. (2013). Öğretmenlik uygulamasına ilişkin nitel bir çalışma. Pamukkale Üniversitesi Eğitim Fakültesi Dergisi, 34(34), 63-73.

Tüfekçi, A. ve Ural, A. (2015). Tutkulu bir mücadele öğretmenlik. Ankara: Pegema Akademi.

Türnüklü, A. (2000). Eğitimbilim araştırmalarında etkin olarak kullanılabilecek nitel bir araştırma tekniği: Görüşme, Kuram ve Uygulamada Eğitim Yönetimi, 6(4), 543-559.

Uygun, S., Ergen, G. ve Öztürk, İ. H. (2011). Türkiye, Almanya ve Fransa'da öğretmen eğitimi programlarında uygulama eğitiminin karşılaştırılması. İlkögretim Online, 10(2), 389-405.

Yaman, S. ve Karamustafaoğlu, S. (2011). Öğretmen adaylarının ölçme ve değerlendirme alanına yönelik yeterlik algı düzeylerinin incelenmesi. Ankara Üniversitesi Eğitim Bilimleri Fakültesi Dergisi, 44(2), 53-72.

Yıldırım, A. (1999). Nitel araştırma yöntemlerinin temel özellikleri ve eğitim araştırmalarındaki yeri ve önemi [Qualitative research methods]. Eğitim ve Bilim Dergisi, 23(112), 7-17.

Yükseköğretim Kurulu (2007). Öğretmen yetiştirme lisans programları. https://www.yok.gov.tr/Documents/Yayinlar/Yayinlarimiz/egitim-fakultesiogretmen-yetistirme-lisans-programlari.pdf adresinden edinilmiştir. 
Yükseköğretim Kurulu (2018). Öğretmen yetiştirme lisans programları. https://www.yok.gov.tr/kurumsal/idari-birimler/egitim-ogretim-dairesi/yeniogretmen-yetistirme-lisans-programlari adresinden edinilmiştir.

Zembat, R, Tunçeli, H. ve Akşin, E. (2015). Okul öncesi öğretmen adaylarının "okul yöneticisi" kavramına ilişkin algılarına yönelik metafor çalışması. Hacettepe Üniversitesi Sağllk Bilimleri Fakültesi Dergisi, 1, 446-459. 


\title{
Analysis of Teaching Practicum in Terms of Duration and Suggestion of a Solution
}

\begin{tabular}{cccc}
\hline ARTICLE TYPE & Received Date & Accepted Date & Published Date \\
Research Article & 03.13 .2019 & 10.04 .2019 & 10.04 .2019 \\
\hline
\end{tabular}

Figen Çam Tosun (iD) 1

Sinop University

\begin{abstract}
This study aims to reveal the views of prospective teachers, teachers, school managers and teaching staffs about the duration of the teaching practicum in teacher training programs. Later, this study aims to make comparisons between Turkey, Finland, Singapore and Germany, and to propose an alternative application for Turkey. In this study, a qualitative research method was preferred. Study group of this study consist of 28 persons. Eight students from the education faculty, eight teachers, four school managers, and eight teaching staff are selected. The structured interview forms have been prepared by the researcher. Content analysis was preferred in the analysis of the data. With this study, firstly, according to the views of prospective teachers, teachers, school managers and teaching staff, inadequacy of teaching practicum applied in Turkey has been revealed. It has been found that teacher practicum in Turkey took place less time than Finland, Singapore and Germany. In order to correct this inadequacy, a teaching practicum system that can be implemented in Turkey has been proposed.

Keywords: Teaching practicum, school experience, practical training, teacher training.
\end{abstract}

${ }^{1}$ Corresponding Author: Assist. Prof. PhD., Faculty of Education, Departmant of Educational Sciences, Email: figencam@gmail.com, https://orcid.org/0000-0001-8303-2179 


\section{Purpose and Significance}

The teaching practicum aims to provide to develop teaching skills in the classroom with teaching and extracurricular activities for prospective teachers. It also allows prospective teachers to teach a specific lesson or lessons in a planned way [Ministry of National Education (Milli Eğitim Bakanlığı-MEB), 2018].

In literature, it is possible to come across many studies in which the teaching practicum is evaluated according to the opinions of the prospective teachers, teachers or teaching staffs (Altıntaş and Görgen, 2014; Arıkan, 2009; Aslan and Sağlam, 2018; Azar, 2003; Baştürk, 2009; Becit, Kurt and Kabakçı, 2009; Gökçe and Demirhan, 2005; Özkilıç, Bilgin and Kartal, 2008 etc.). In these studies, the problems encountered in the course are discussed. Studies mostly focus on the fact that this course is not effective and efficient. The fact that teaching practicum is not effective and efficient may be related to the time limitation of the course. Teaching practicum takes place less than 30 days in very few countries in the world including Turkey. If prospective teachers are more confronted with real situations, they can better deal with problems. For these reasons, the problem of this research is that the students of the Faculty of Education take a short time of teaching practicum.

This study aims to reveal the views of prospective teachers, teachers, school managers and teaching staffs about the duration of the teaching practicum in teacher training programs. Later, this study aims to make comparisons between Turkey, Finland, Singapore and Germany, and to propose an alternative application for Turkey. In this context, the following questions will be answered.

1. What are the views of prospective teachers about the duration of teaching practicum in teacher training programs?

2. What are the views of the teachers about the duration of teaching practicum in teacher training programs?

3. What are the views of the school managers about the duration of teaching practicum in teacher training programs?

4. What are the views of teaching staff about the duration of teaching practicum in teacher training programs?

5. How is teaching practicum performed in Turkey, Singapore, Finland and Germany?

6. Is there an alternative practice in place of teaching practicum in teacher training programs?

\section{Method}

In this section, research model, working group, data collection tool, data collection and analysis are mentioned. 
In this study, a qualitative research method was preferred to reveal the opinions of the components participating in teaching practicum about the duration of the course.

In order to determine the study group, the purposeful sampling method was preferred. Firstly, two schools were selected. One of the schools is located in the city center. The facilities of the school located in the city center are in very good condition and the socio-economic and cultural structure of the parents of this school are high. The other school is quite far from the city center. Facilities of other school are not in good condition as the first school, and the socio-economic and cultural structure of parents of other school are low. Study group of this study consist of 28 persons. Eight students from the education faculty, eight teachers, four school managers, and eight teaching staff are selected.

The structured interview forms, which were created in the same context, have been prepared for the prospective teachers, teachers, school managers and teaching staffs who took the teaching practicum course. The semi-structured interview forms prepared by the researcher were submitted to the expert opinion (experts with $\mathrm{PhD}$ including two in educational management, and one in measurement and evaluation fields).

Data were collected by visiting schools for teachers and school managers. The data of prospective teachers and teaching staffs were also gathered in the faculty. Content analysis was preferred in the analysis of the data.

\section{Results}

According to the opinions of prospective teachers, teachers, school managers and teaching staffs, it was found out that prospective teachers who went to teaching practicum once a week did not recognize children in their classrooms.

The prospective teacher is expected to develop communication skills such as giving instructions, setting up clear statements, acting in accordance with the current situation, and telling the student what he wants. In this study, it was found that, according to the majority of both the prospective teachers and the other components, prospective teachers could not communicate, or they partially communicate with students.

In this study, it was found that the classroom management skill of the prospective teachers was not at the desired level.

More than half of the teachers and teaching staffs think that prospective teachers could not create an effective learning environment. Half of the prospective teachers think that they partially create an effective learning environment.

Prospective teachers make assessments within the scope of the lecture. They did not participate in general assessment and evaluation activities. 
It is thought that prospective teachers are trying to adapt to the school, that they do not feel to belong to the school, and that belonging to the profession develops over time. It is seen that prospective teachers do not go to school except the day they participate in teaching practicum.

According to the findings of this research, prospective teachers communicate with the teachers. However, this communication is limited to the subject, which needs to be done or suggestions. Prospective teachers do not use the teachers' room and do not participate in the general process related to school or education.

A similar situation has arisen in the communication of prospective teachers with the school administration. It was revealed that prospective teachers contacted the deputy manager when they needed something.

In this study, it has been seen that prospective teachers did not contribute much to the school and did not participate in school activities.

The majority of prospective teachers, teachers, school managers and teaching staff participating in the study do not consider the duration of the teaching practicum in teacher training programs as adequate.

\section{Discussion and Conclusions}

Prospective teachers couldn't recognize children in their classrooms. According to a study conducted by Özmen (2008), prospective teachers expressed that they did not know how to treat students at different grades.

It is quite important that prospective teachers communicate correctly with the students during their education. In the study of Akpınar, Çolak and Yiğit (2012), it has been found out that according to teachers, one of the most insufficient skills of prospective teachers was communication skill.

It is also supported by the findings of the study conducted by Akpınar et al. (2012) in the terms of insufficient classroom management skills of prospective teachers.

Findings related to the ability of prospective teachers to create an effective learning environment are supported in the literature. Karadüz, Eser, Şahin and İlbay (2009) showed that after participating in teaching practicum, there was no change in prospective teachers' competencies of using teaching methods and techniques, summarizing and giving appropriate feedback.

According to the study conducted by Yaman and Karamustafaoğlu (2011), prospective teachers do not consider themselves adequate within the scope of measurement and evaluation activities.

Prospective teachers should be in touch with the teachers so that they can understand the school culture. In their study, Çetintaş and Genç (2005) found that half of the prospective teachers used the teacher's room, $30 \%$ had avoided using and the 
rest had never used them. $40 \%$ of prospective teachers stated that they did not meet other teachers. Becit, Kurt and Kabakçı (2009) found that teaching practicum positively affects prospective teachers' perceptions of the profession. In the study of Altıntaş and Görgen (2014), prospective teacher stated that they determined the decisions about whether they were suitable for the profession or not with the teaching practicum course. Çetintaş and Genç (2005) found that only $20 \%$ of prospective teachers take extracurricular responsibilities such as school trips, administrative affairs, flag ceremony.

The literature supports the results of this study (Akpınar et al., 2012; Altıntaş and Görgen, 2014; Aslan and Sağlam, 2018; Eraslan, 2009; Gökçe and Demirhan, 2005; Karadüz et al., 2009; Şaşmaz-Ören, Sevinç and Erdoğmuş, 2009; Şimşek, Alkan and Erdem, 2013).

In this study, Turkey, Finland, Singapore and Germany were compared in the scope of teaching practicum. Other countries except Turkey apply teaching practicum throughout the whole educational process and the classes are completely left to prospective teachers for a certain period of time in the last stage of their teacher training education.

In this study so far, it has been tried to reveal the inadequacy of the duration of teaching practicum. In the last part, it has been proposed an alternative practice for teaching practicum in Turkey. The first practice can be performed in the first period of the second grade for observation purposes. The second practice can be applied thematically in the first period of the third grade in the form of transforming these theoretical courses into practice. The third practice can be implemented in the first period of the fourth grade and in the form of one-day responsibility as Teacher Practicum I. In the last semester of the fourth year, the prospective teacher can spend a whole semester at the practice school as Teacher Practicum II.

With this study, firstly, according to the views of prospective teachers, teachers, school managers and teaching staff, inadequacy of teaching practicum applied in Turkey has been revealed. It has been found that teacher practicum in Turkey took place less time than in other countries. In order to correct this inadequacy, a teaching practicum system that can be implemented in Turkey has been proposed. 